\title{
Autoritatif Hukum Penentuan Awal Bulan di Indonesia
}

\author{
Fajri Assiddiq ${ }^{1 *}$ \\ Universitas Is lam Negeri Sumatera Utara \\ "Email : fajriassiddiq434@gmail.com
}

\begin{abstract}
Determination of the beginning of the lunar month conducted by the government to realize the benefit of Muslims. The law has stipulated that issues of good quality are necessary and justified by the interference of ulil amri, the government. This was done in order to create public benefit. The government in setting the beginning of the month is not because of authority but authoritative. This means that the authority is that the government is only based on the authority of power while authoritative is based on shar'i arguments.
\end{abstract}

Artikel Info

Received:

27 Februari 2020

Revised:

11 Maret 2020

Accepted:

08 April 2020

Published:

02 Juni 2020

\section{Keywords: Authoritative, Legal.}

\begin{abstract}
Abstrak
$\overline{\text { Penentuan awal bulan kamariah yang dilakukan pemerintah }}$ untuk mewujudkan kemashlahatan umat Islam. Hukum telah mengatur bahwa persoalan yang bersifat kemashlahatan perlu dan dibenarkan adanya campur tangan ulil amri, pemerintah. Ini dilakukan agar terc ipta ke mashlahatan umum. Pemerintah dalam menetapkan awal bulan bukan karena otoritas tetapi autoritatif. otoritas adalah bahwa pemerintah hanya berdasarkan kewenangan kekuasaan saja sedangkan autoritatif berdasarkan argumen-argumen syar' i.
\end{abstract}

\section{Kata Kunci : autoritatif, hukum.}

\section{A. Pendahuluan}

Hukum di indonesia merupakan campuran dari sistem hukum eropa,hukum agama,dan hukum adat.sebagian besar sistem yang dianut ,baik perdata maupun pidana,berbasis pada pada hukum eropa ,khususnya dari belanda .karena aspek sejarah masa lalu Indonesia yang merupakan wilayah jajaha hindia be landa (Netherlandsch-indie).hukum gama karena sebagian besar masyarakat menfanut agama islam.,maka dominasi hukum atau syariat islam lebih dominan terutama dibidang perkawinan,keke luargaan, dan warisan.

selain itu diindonesia juga terdapat hukum adat yang diserap dalam perundangan- undangan 


\section{AL-MARSHAD: JURNAL ASTRONOMI ISLAM DAN ILMU-ILMU BERKAITAN ISSN 2442-5729 (print) || ISSN 2598-2559 (online) \\ http://jurnal.umsu.ac.id/index.php/almarshad \\ DOI: $10.30596 /$ jam.v\% vi\% i.4366 || Vol. 6, No. 1. Juni 2020}

atau yurisprudensi (yang merupakan penerusan dari aturan-aturan setempat dan budaya yg ada diwilayah indonesia Dinegara yang menganut sistem hukum Anglo Sakson, ilmu hukum dikenal dengan istilah jurisprudanceyang berarti ilmu hukum, tetapi pada sisi lain juga dikenal dengan istilah legal theory yang di Indonesia diistilahkan dengan teori hukum.

Ilmu Hukum itu dikenal dengan sebutan dalam bahasa inggris jurisprudence. Berasal dari kata jus atau juris yang artinya " hukum atau hak, kata prudence berarti " melihat ke depan atau mempunyai keahlian”. Arti harfiah secara umum dari kata jurisprudence adalah "ilmu yang mempelajari hukum".

Untuk memberikan gambaran dan pemahaman tentag arti sesungguhnya dari ilmu hukum, dibawah ini sejumlah juris mengemukakan pendapatnya sebagai berikut :

1. Ulpian menyebutnya sebagai pengetahuan mengenai masalah yang bersifat surgawi dan manusiawi, pengetahuan tentang yang benar dan yang tidak benar.

2. Stone mengatakan ilmu hukum merupakan penyelidikaan oleh para ahli hkum tentang norma-norma, cita-cita dan teknik-teknik hukum dengan menggunakan pengetahuan yang diperoleh dari berbagai disiplin diluar hukum yang mutakhir.

3. Fitsgerald mengatakan nama yang diberikan kepada suatu cara untuk mempelajari hukum, suatu penyelidikan yang bersifat abstrak, umum dan teoritis, yang berusaha untuk mengungkapkan asas-asas yang pokok dari hukum dan sistem hukum. ${ }^{1}$

Kurang lebih dari 200 tahun yang lalu Immanuel kant pernah menulis sebgai berikut "Noch suchen die juristen eine Definition zu ihrem Beggife von Recht” ( Masih juga para sarjana hukum mencari-mencari suatu definisi tentang hukum).sesungguhnya ucapan kant ini hingga kini masih berlaku, sebab telah banyak sarjana hukum mencari suatu batasan tentang hukum namun setiap pembatasan tentang hukum yang diperoleh belum pernah memberi kepuasaan ${ }^{2}$

Jika berbicara tentang Hukum, secara sederhana segera terlintas dalam fikiran kita peraturan-peraturan atau seperangkat norma yang mengatur tingkah-laku manusia dalam suatu masyarakat, baik peraturan atau norma itu berupa kenyataan yang tumbuh dan berkembang dalam masyarakat. ${ }^{3}$ "Hukum

\footnotetext{
${ }^{1}$ Marwan Mas. Pengantar Ilmu Hukum .(Ghalia Indonesia.2014), h. 11-13.

2 Kansil. Pengantar Ilmu Hukum dan Tata Hukum Indonesia. (Tanggerang Balai Pustaka, 2018). h. 34-38

${ }^{3}$ Mohammad Daud Ali, Hukum Islam Pengantar Ilmu Hukum dan Tata Hukum Islam Indonesia, (Jakarta: Rajawali Pers, 2010) h. 38.
} 


\section{AL-MARSHAD: JURNAL ASTRONOMI ISLAM DAN ILMU-ILMU BERKAITAN ISSN 2442-5729 (print) || ISSN 2598-2559 (online) \\ http://jurnal.umsu.ac.id/index.php/almarshad \\ DOI: $10.30596 /$ jam.v\% vi\% i.4366 || Vol. 6, No. 1. Juni 2020}

adalah seperangkat norma tentang apa yang benar dan apa yang salah, yang dibuat atau diakui eksitensinya oleh pemerintah, yang dituangkan baik sebagai aturan tertulis (peraturan) ataupun yang tidak tertulis, yang mengikat dan sesuai dengan kebutuhan masyarakatnya secara keseluruhan, dan dengan ancaman sanksi bagi pe langgar aturan itu".

Jadi, yang dimaksud sebagai "Hukum" bukan hanya "undang-undang", karena "undang-undang" hanyalah bagian kecil dari hukum.

Hukum tidak harus dibuat oleh pemerintah, tetapi harus diakui berlakunya oleh pemerintah. Sebagai contoh, hukum islam dan hukum adat yang hingga batas tertentu juga berlaku di Indonesia, bukan produk pemerintah, tetapi jelas diakui berlakunya oleh pemerintah. Demikian pula konvensi-konvensi internasional, buku produk pemerintah, tetapi agar dapat berfungsi sebagai hukum disuatu Negara, harus diratifikasi oleh Negara tersebut .

Dengan demikian, yang kita maksudkan sebagai supremasi hukum adalah suatu keadaan dimana "hukumanlah yang tertinggi”, hukum mengatasi kekuasaan lain termasuk kekuasaan politik. Dengan kata lain, Negara yang dapat dikatakan telah mewujudkan "supremasi hukum" adalah Negara yang sudah mampu menempatkan "hukum sebagainpanglima", bukannya hukum hanya menjadi sekedar "pak turut" dari kepentingan politik tertentu yang jauh dan kepentingan rakyat secara keseluruhannya.

Kita jangan menyempitkan pengertian "supremasi hukum" hanya sekedar "supremasi undang-undang”. Akibatnya Indonesia sekarang yang sudah "hujan undang-undang", justru masih belum membaik kondisi hukumnya. Hal itu disebabkan sebagian undang-undang kita dan sebagian penegak hukum mengabaikan tiga ide dasar hukum (sebagaimana yang dikemukakan oleh Gustuv Radbruch), yaitu : keadilan, kemanfaatan, dan kepastian.

Oleh karena itu, menurut penulis, kita tidak sekedar menggunakan istilah "supremasi hukum", melainkan lebih tepat jika menggunakan istilah Supremasi Hukumdan Keadilan, sebab salah satu faktor utama keterpurukan hukum kita di Indonesia, pelaksanaan hukum penegakan hukum sering sangat mengabaikan "rasa keadilan

masyarakat", dan hanya terpaku pada "formalitas" dan "prosedur" belaka. Lebih celaka lagi justru dengan melakukan "pembenaran" melalui undang-undang dan ketentuan lainnya, para koruptor biasanya

berlindung dibalik itu. Masyarakat senantiasa 


\section{AL-MARSHAD: JURNAL ASTRONOMI ISLAM DAN ILMU-ILMU BERKAITAN ISSN 2442-5729 (print) || ISSN 2598-2559 (online) \\ http://jurnal.umsu.ac.id/index.php/almarshad \\ DOI: $10.30596 /$ jam.v\% vi\% i.4366 || Vol. 6, No. 1. Juni 2020}

diatur oleh berbagai norma

sosail secara kebersamaan, yaitu norma hukum, norma moral atau etika, norma agama, norma kesopanan, norma adat, dan norma disiplin. Adakalanya suatu perbuatan diatur oleh lebih dari satu norma secara bersama-sama, contohnya : "Membunuh", bukan hanya dilarang oleh norma hukum dan diancam hukuman oleh KUH Pidana, melainkan juga dilarang oleh norma moral, norma agama, dan norma adat, tetapi ada juga perbuatan yang hanya diatur oleh norma hukum, dan tidak diatur oleh norma lain, misalnya untuk mendirikan suatu perseroan terbatas, harus dengan akta notaris. ${ }^{4}$

\section{B. Metodologi Penelitian}

Metodologi penelitian merupakan cara melakukan sesuatu dengan menggunakan pikiran secara seksama untuk mencapai suatu tujuan. Sedangkan penelitian adalah suau kegiatan untuk mencari, mencatat, merumuskan dan menganalisis sampai menyusun laporannya. ${ }^{5}$ Metode merupakan suatu cara yang tepat untuk melakukan sesuatu dalam mencapai tujuan dengan alat dan tekhnik tertentu. Metode penelitian adalah cara atau setrategi menyeluruh untuk

\footnotetext{
${ }^{4}$ Achmad Ali. Menguak Realitas Hukum, (Jakarta : Prenada Media Group, 2008), hlm2-3

${ }^{5}$ Cholid Narbuko, Abu Achmadi, Metodologi Penelitian, (Jakarta, PT. Bumi Aksara, 2015), h.1.
}

menemukan atau memperoleh data yang diinginkan, metode pene litian merupakan cara ilmiah yang digunakan untuk mendapatkan data dengan tujuan tertentu ${ }^{6}$. Teknik pengumpulan data yang digunakan dalam penelitian ini meliputi studi kepustakaan

\section{Hasil dan Pembahasan}

Beberapa definisi hukum sesungguhnya apabila kita meneliti benar-benar, akan sukarlah bagi kita untuk memberi defenisi hukum tentang hukum. akan tetapi walaupun tak mungkin diadakan suatu batasan yang lengkap tentang apakah hukum itu, namun Drs E.Utrecht, S.H. dalam bukunya yang berjudul "Pengantar Dalam Hukum Indonesia " (1953) Telah mencoba membuat suatu bahasan, yang maksudnya sebagai pe gangan bagi orang yang sedang mempelajari Ilmu Hukum.

Utrecht memberikan batasan Hukum sebagai berikut : “ Hukum itu adalah himpunan peraturan-peraturan (perintahperintah dan larangan-larangan) yang mengurus tata-tertib suatu masyarakat dank arena itu harus ditaati oleh masyarakat itu ". Selain Utrecht juga beberapa Sarjana Hukum Indonesia la innya te lah berusaha merumuskan tentang apakah Hukum itu, yang diantaranya ialah:

\section{a . S.M. Amin, S.H.}

\footnotetext{
Mahi M Hikmat, Metode Penelitian, (Yogyakarta, Graha Ilmu, 2011), h.30.
} 


\section{AL-MARSHAD: JURNAL ASTRONOMI ISLAM DAN ILMU-ILMU BERKAITAN ISSN 2442-5729 (print) || ISSN 2598-2559 (online) \\ http://jurnal.umsu.ac.id/index.php/almarshad \\ DOI: $10.30596 /$ jam.v\% vi\% i.4366 || Vol. 6, No. 1. Juni 2020}

Dalam buku beliau yang berjudul "Bertamasya ke Alam Hukum”, hukum dirumuskan sebagai berikut : “ Kumpulankumpulan peraturan-peraturan yang terdiri dari norma dan sanksi-sanki itu disebut hukum dan tujuan hukum itu adalah mengadakan ketatatertiban dalam pergaulan manusia, sehingga keamanan dan ketertiban terpelihara".

b. J.C.T. Simorangkir, S.H. dan Woerjono Sastropranoto, S.H.

Dalam buku yang disusun bersama berjudul "Pelajaran Hukum Indonesia" telah diberikan definisi hukum seperti berikut: "Hukum itu ialah peraturanperaturan yang bersifat memaksa, yang menentukan tingkah laku manusia dalam lingkungan masyarakat yang dibuat oleh Badan-badan resmi yang berwajib, pelanggaran mana terhadap peraturanperaturan tadi berakibatkan diambilnya tindakan, yaitu dengan hukum tertentu" .

\section{c. M.H. Tirtaatmidjaja, S.H.}

Dalam buku beliau "Pokok-Pokok Hukum Perniagaan" ditegaskan, bahwa "Hukum ialah semua aturan (norma) yang harus diturut dalam tingkah laku tindakantindakan dalam pergaulan hidup dengan ancaman mesti mengganti kerugian jika melanggar aturan-aturan itu akan membahayakan diri sendiri atau harta, umpamanya orang yang kehilangan kemerdekaannya , didenda dan sebagainya". 7

Beberapa definisi yang akan diberikan dibawah ini menunjukkan bahwa antara para ahli Hukum Tata Negara masih terdapat perbedaan pendapat, Perbedaan ini antara lain disebabkan karena masing-masing ahli berpendapat, bahwa apa yang mereka anggap penting akan menjadi titik berat dalam merumuskan arti Hukum Tata Negara. Akan tetapi juga

perbedaan pendapat itu disebabkan karena pengaruh lingkungan dan pandangan hidup berlainan.

\section{a. van Vollenhoven}

Hukum Tata Negara mengatur semua masyarakat hukum atasan dan masyarakat hukum bawahan menurut tingkatannya dan dari masing-masing itu menentukan wilayah lingkungan rakyatnya dan akhirnya menentukan badan-badan dan fungsinya masing-masing yang berkuasa dalam lingkungan masyarakat, serta menentukan susunan dan wewenangnya dari badan-badan tersebut.

\section{b. Scholten}

Hukum Tata Negara adalah hukum yang mengatur organisasi dari pada Negara. Scholten dapat disimpulkan, bahwa dalam

\footnotetext{
${ }^{7}$ Kansil. Pengantar Ilmu Hukum dan Tata Hukum Indonesia (Tanggerang : Balai Pustaka 2018), h. 34-38
} 


\section{AL-MARSHAD: JURNAL ASTRONOMI ISLAM DAN ILMU-ILMU BERKAITAN ISSN 2442-5729 (print) || ISSN 2598-2559 (online) \\ http://jurnal.umsu.ac.id/index.php/almarshad \\ DOI: $10.30596 /$ jam.v\% vi\% i.4366 || Vol. 6, No. 1. Juni 2020}

organisasi Negara ini telah dicakup bagaimana kedudukan organ-organ dalam Negara itu, hubungan, hak dan kewajiban, serta tugasnya masing-masing, akan tetapi tidak dibicarakan lebih lanjut bagaimanakah nasib hak azasi manusia serta kewarganegaraannya yang sangat penting itu.

\section{c. van derr pot}

Hukum Tatat Negara adalah peraturanperaturan yang menentukan badan-badan yang diperlukan serta wewenangnya masing-masing, hubungannya satu dengan yang lainnya dan hubungannya dengan individu-individu.

\section{d. Logemann}

Hukum Tata Negara adalah hukum yang mengatur organisasi Negara.

Menurut Logemann jabatan merupakan pengertian yuridis dari fungsi sedangkan fungsi adalah pengertian bersifat sosiologis. Karena Negara merupakan organisasi yang terdiri atas fungsi-fungsi dalam hubungannya satu dengan yang lainnya serta ke seluruhannya, maka dalam arti yuridis, Negara merupakan organisasi dari jabatan-jabatan. ${ }^{8}$

8 Moh. Kusnardi \& Hermaily Ibrahim. Hukum Tata Negara Indonesia. (Pusat Studi Hukum Tata Negara Universitas Indonesia,1981)

\section{Kesulitan mendefinisikan Hukum}

Perkembangan sejarah kehidupan umat manusia mempengaruhi pula keberadaan hukum dalam masyarakat. Untuk mengetahui perkembangan hukum dalam masyarakat, digunakan metode kesejarahan atau sejarah perkembangan hukum. Demikian pula, metode yang digunakan untuk mengetahui bagaimana hubungan hukum dengan manusia, adalah metode sosiologis melalui sosiologi hukum yang mengkaji hukum sebagai kenyataan atau gejala masyarakat, seperti ospek ekonomi, aspek politik, aspek sosial, dan aspek budaya.

Definisi hukum yang sampai saat ini belum disepakati oleh para ahli hukum, menunjukkan bahwa untuk membangun suatu definisi yang lengkap, sistematis,padat,dan jelas, memang sangat sulit. termasuk keberadaan hukum bagi orang yang baru mempe lajarinya.

\section{Kegunaan mengetahui definisi hukum}

sebagaimaa disiplin ilmu pengetahuan lainnya, keberadaan definisi tentang suatu hal dianggap sangat penting untuk dapat mengetahui dan memahami substansi ilmu pengetahuan tersebut. Demikian pula ilmu hukum, menganggap definisi hukum lebih mendalam. Jika pun selama ini belum ada suatu definisi hukum yang lengkap dan tuntas yang dapat diterima oleh semua kalangan, bukan berarti 


\section{AL-MARSHAD: JURNAL ASTRONOMI ISLAM DAN ILMU-ILMU BERKAITAN ISSN 2442-5729 (print) || ISSN 2598-2559 (online) \\ http://jurnal.umsu.ac.id/index.php/almarshad \\ DOI: $10.30596 /$ jam.v\% vi\% i.4366 || Vol. 6, No. 1. Juni 2020}

tidak ada definisi hukum. Begitu banyak definisi hukum dikemukakan oleh ilmuwan hukum yang tentu saja sangat berguna dalam hal berikut.

1. berguna sebagai pegangan awal bagi orang yang ingin mempelajari hukum, khususnya bagi kalangan pemula

2. berguna bagi kalangan yang ingin lebih jauh memperdalam teori hukum, ilmu hukum, filsafat hukum, dan sebagainya.

Salah seorang sosiolog, mengakui bahwa dalam kenyataan hukum memang tidak akan pernah dapat didefenisikan secara lengkap,jelas, dan tegas.

Namun, Arlond juga menyadari bahwa bagaimanapun para juris tetap akan terus berjuang mecari bagaimana hukum didefinisikan, sebab definisi hukum merupakan bagian yang substansial dalam memberi arti keberadaan hukum sebagai ilmu. Hukum juga merupakan sesuatu yang rasional dan dimungkinkan untuk dibuatkan definisi sebagai penghormatan para juris terhadap eksistensi hukum.

Memahami pandangan Arlond, sehingga belum adanya definisi hukum yang lengkap, jelas dan sistematis seperti dikemukakan oleh Immuel Kant diatas, juga bukan berarti berhentinya ilmuwan hukum mencari dan menemukan rumusan yang kemungkinan dapat merangkup seluruh aspek yang melingkupi hukum, kendati sejumlah definisi hukum yang dikemukakan oleh para pakar hukum tersebut belum juga disepakati bersama. ${ }^{9}$

\section{Tujuan Hukum}

Dalam pergaulan masyarakat terdapat aneka macam hubungan antara anggota masyarakat, yakni hubungan yang ditimbulkan oleh kepentingan-kepentingan anggota

masyarakat itu. Dengan banyak dan aneka ragamnya hubungan itu, para anggota masyarakat memerlukan aturan-aturan yang dapat menjamin keseimbangan agar dalam hubungan- hubungan itu tidak terjadi kekacauan dalam masyarakat. Untuk menjamin kelangsungan keseimbangan dalam perhubungan antara anggota masyarakat untuk patuh mentaatinya, menyebabkan terdapatnya keseimbangan dalam perhubungan antara anggota masyarakat, diperlukan aturan-aturan hukum yang diadakan atas kehendak dan keinsyafan tiap-tiap ang gota masyarakat itu.

Peraturan-peraturan hukum yang bersifat mengatur dan memaksa anggota masyarakat untuk patuh mentaatinya, menyebabkan terdapatnya keseimbangan dalam tiap perhubungan dalam masyarakat. Setiap hubungan dalam peraturan hukum yang ada dan berlaku dalam masyarakat. Setiap

9 Marwan Mas . Pengantar Ilmu Hukum. (Jakarta : Ghalia Indonesia, 2014) 


\section{AL-MARSHAD: JURNAL ASTRONOMI ISLAM DAN ILMU-ILMU BERKAITAN ISSN 2442-5729 (print) || ISSN 2598-2559 (online) \\ http://jurnal.umsu.ac.id/index.php/almarshad \\ DOI: $10.30596 /$ jam.v\% vi\% i.4366 || Vol. 6, No. 1. Juni 2020}

pelanggar peraturan hukum yang ada, akan dikenakan sanksi yang berupa hukuman sebagai reaksi terhadap perbuatan yang melanggar hukum yang dilakukannya.

Untuk menjaga agar peraturan-peraturan hukum itu dapat berlangsung terus dan diterima oleh seluruh anggota masyarakat, maka peraturan-peraturan hukum yang ada harus sesuai dan tidak boleh bertentangan dengan asas-asas keadilan dari masyarakat tersebut. ${ }^{10}$

\section{Definisi hukum dari sudut keilmuan dan politik.}

Setiap usaha untuk mendefinisikan sebuah konsep harus dimulai dari penggunaannya yang umum terhadap kata tersebut, yang menunjukkan konsep yang dibicarakan. Dalam mendefinisikan konsep hukum, kita harus memulai dengan mengkaji beberapa pertanyaan berikut: apakah fenomenal sosial yang lazim disebut "hukum" menampilkan suatu karakteristik umum yang membedakannya dari fenomena sosial lain dari jenis yang sama? Dan apakah karakteristik ini sedemikian sehingga dapat dijadikan dasar dari suatu konsep yang berguna bagi pengetahuan tentang kehidupan sosial? Orang harus memulainya dari kemungkinan pemakaian istilah

\footnotetext{
${ }^{10}$ Kansil. Pengantar Ilmu Hukum dan Tata
} Hukum Indonesia. (Tanggerang : Balai Pustaka, 2018), h. 40 "hukum" yang paling luas. Mungkin karakteristik yang kita cari semacam itu bisa ditemukan. Mungkin penggunaan yang sesungguhnya sedemikian longgar sehingga fenomena yang disebut "hukum" tidak menunjukkan suatu karakteristik umum yang benar-benar penting. Namun jika karakteristik semacam itu dapat ditemukan, kita benarkan untuk memasukkannya kedalam definisi. Ini tidak berarti bahwa kita tidak dibenarkan untuk merumuskan suatu konsep hukum yang lebih sempit, yang tidak mencakup semua fenomena yang lazim disebut "hukum". kita juga dapat berinisiatif mendefinisikan istilahistilah yang hendak kita gunakan sebagai perkakas dalam pekerjaan intelektual kita. Yang menjadi persoalan adalah apakah istilah tersebut akan bermanfaat bagi tujuan teoritik yang kita kehendaki dari istilah-istilah itu.

Konsep hukum yang tingkatannya kira-kira sama dengan kelaziman penggunaannya jika kondisi-kondisi lainnya sama jelas harus lebih diutamakan dari konsep yang hanya dapat diterapkan kepada segolongan fenomena yang jauh lebih sempit. Kita ambil satu contoh. Bahkan sejak kebangkitan Bolshevisme, Sosialisme, dan Fascisme pun, orang berbicara tentang "hukum" Rusia,Jerman, dan Italia. Namun demikian, tidak ada yang akan

menghalangi upaya kita untuk memasukkan suatu kebebasan atau kepemilikan pribadi 


\section{AL-MARSHAD: JURNAL ASTRONOMI ISLAM DAN ILMU-ILMU BERKAITAN ISSN 2442-5729 (print) || ISSN 2598-2559 (online) \\ http://jurnal.umsu.ac.id/index.php/almarshad \\ DOI: $10.30596 /$ jam.v\% vi\% i.4366 || Vol. 6, No. 1. Juni 2020}

sekecil apapun kedalam definisi tatanan hukum yang kita buat. Satu akibat dari pemakaian definisi seperti itu adalah bahwa tatanan sosial yang berlaku di Rusia, Italia, dan Jerman tidak lagi dapat dianggap sebagai tatanan hukum, walapun tatanan sosial tersebut memiliki unsut-unsur terpenting yang sama seperti tatanan sosial dari Negara-negara demokratis.

Konsep yang dise butkan diatas yang sebenarnya terdapat di dalam buku-buku tentang filsafat hukum juga menunjukkan bagaimana bias dapat mempengaruhi definisi hukum. konsep hukum didalam buku ini dikembangkan sejalan dengan cita-cita keadilan tertentu, yaitu cita-cita demokrasi dan liberalisme. ${ }^{11}$

\section{Pendapat para sarjana tentang hukum}

Hampir semua Sarjana Hukum memberikan pembatasan Hukum yang berlainan, kata Prof. van Apeldoorn. Penulis-penulis Ilmu pengetahuan Huum di Indonesia juga sependapat dengan Prof. van Apeldoorn, seperti Prof. Sudirman Kartohadiprojo, S.H. dan Drs. E. Utrecht, S.H . Dalam buku beliau yang berjudul “ Pengantar Tata Hukum di Indonesia" (1956), jilid 1 pada halaman 1,

11 Hans Kelsen,. Teori Hukum dan Negara (Bandung : Nus a Media 2006), h. 4-5
Prof.Sudirman Kartohadiprodjo S.H. menulis sebagai berikut, “... jikalau kita menanyakan apakah yang dinamakan Hukum, maka kita akan menjumpai tidak adanya persesuaian pendapat. Berbagai perumusanlah yang dikemukakan".

Sebagai gambaran, Prof. sudiman Kartohadiprodjo, S.H. lalu memberikan contoh- contoh tentang definisi Hukum yang berbeda-beda, sebagai berikut :

1. Aristoteles : Hukum Khusus adalah apa yang diterapkan oleh setiap komunitas dan berlaku untuk anggotanya sendiri. Hukum universal adalah hukum alam.

2. Groutius : Hukum adalah aturan tindakan moral yang mewajibkan apa yang benar.

3. Hobbes : Dimana sebagai hukum benar adalah kat-katanya bahwa dengan benar menguasai orang lain.

4. Prof. Mr Dr C. van Vollenhoven : hukum adalah fenomena interaksi ge lisah anatara bendung dan konta bendung .

5. Philip S. James,M.a.: Hukum adalah badan aturan untuk pedoman perilaku manusia yang dikenakan,dan ditegakkan diantara anggota Negara tertentu. ${ }^{12}$

\section{Kesimpulan}

Jika berbicara tentang Hukum, secara sederhana terlintas dalam fikiran kita

\footnotetext{
${ }^{12}$ Kansil. Pengantar Ilmu Hukum dan Tata
} Hukum Indonesia. (Tanggerang : Balai Pustaka, 2018), h. 35 


\section{AL-MARSHAD: JURNAL ASTRONOMI ISLAM DAN ILMU-ILMU BERKAITAN ISSN 2442-5729 (print) || ISSN 2598-2559 (online) \\ http://jurnal.umsu.ac.id/index.php/almarshad \\ DOI: $10.30596 /$ jam.v\% vi\% i.4366 || Vol. 6, No. 1. Juni 2020}

peraturan-peraturan atau seperangkat norma yang mengatur tingkah-laku manusia dalam suatu masyarakat, baik peraturan atau norma itu berupa kenyataan yang tumbuh dan berkembang dalam masyarakat. "Hukum adalah seperangkat norma tentang apa yang benar dan apa yang salah, yang dibuat atau diakui eksitensinya oleh pemerintah, yang dituangkan baik sebagai aturan tertulis (peraturan) ataupun yang tidak tertulis, yang mengikat dan sesuai dengan kebutuhan

masyarakatnya secara keseluruhan, dan dengan ancaman sanksi bagi pelanggar aturan itu".

Jadi, yang dimaksud sebagai "Hukum" bukan hanya "undang-undang", karena "undang-undang" hanyalah bagian kecil dari hukum. Hukum tidak harus dibuat oleh pemerintah, tetapi harus diakui berlakunya oleh pemerintah. Sebagai contoh, hukum islam dan hukum adat yang hingga batas tertentu juga berlaku di Indonesia, bukan produk pemerintah, tetapi jelas diakui berlakunya oleh pemerintah. Demikian pula konvensi-konvensi internasional, buku produk pemerintah, tetapi agar dapat berfungsi sebagai hukum disuatu Negara, harus diratifikasi oleh Negara tersebut Dan kita juga banyak memahami definisi hukum dari para-para ahli tersebut .

\section{E. Saran}

Sebagaimaa disiplin ilmu pengetahuan lainnya, keberadaan definisi tentang suatu hal dianggap sangat penting untuk dapat mengetahui dan memahami substansi ilmu pengetahuan tersebut. Demikian pula ilmu hukum, menganggap definisi hukum lebih mendalam. Jika pun selama ini belum ada suatu definisi hukum yang lengkap dan tuntas yang dapat diterima oleh semua kalangan, bukan berarti tidak ada definisi hukum. Begitu banyak definisi hukum dikemukakan oleh ilmuwan hukum yang tentu saja sangat berguna dalam hal berikut.

1. berguna sebagai pegangan awal bagi orang yang ingin mempelajari hukum, khususnya bagi kalangan pemula

2. berguna bagi kalangan yang ingin lebih jauh memperdalam teori hukum, ilmu hukum, filsafat hukum, dan sebagainya.

\section{Daftar Pus taka}

Achmad Ali. 2008 .Menguak Realitas Hukum, Jakarta: Prenada Media Group, h. 2-3.

Hans Kelsen 2006. Teori Hukum dan Negara Bandung : Nusa Media h. 4-5.

Kansil.2018. Pengantar Ilmu Hukum dan Tata 
Hukum Indonesia. Tanggerang :

Balai Pustaka h. 34-38.

Marwan Mas. 2014. Pengantar Ilmu

Hukum. Ghalia Indonesia. h.11-13.

Mohammad Daud Ali, 2010. Hukum Islam

Pengantar Ilmu Hukum dan Tata

Hukum Islam Indonesia, Jakarta:

Rajawali Pers. h. 38.

Moh. Kusnardi \& Hermaily Ibrahim. 1981.

Hukum Tata Negara Indonesia.

Pusat Studi Hukum Tata Negara

Universitas Indonesia. 